\title{
Plasminogen activation system in oral cancer: Relevance in prognosis and therapy (Review)
}

\author{
MARZENA WYGANOWSKA-ŚWIĄTKOWSKA ${ }^{1}$ and JERZY JANKUN ${ }^{2-4}$ \\ ${ }^{1}$ Department of Conservative Dentistry and Periodontology, Poznan University of Medical Sciences, Poznań 60-820, Poland; \\ ${ }^{2}$ Urology Research Centre, Department of Urology, College of Medicine, University of Toledo, Toledo, OH 43614, USA; \\ ${ }^{3}$ Protein Research Chair, Department of Biochemistry, College of Sciences, King Saud University, Riyadh 11451, \\ Kingdom of Saudi Arabia; ${ }^{4}$ Department of Clinical Nutrition, Medical University of Gdańsk, Gdańsk 80-211, Poland
}

Received March 12, 2015; Accepted May 4, 2015

DOI: 10.3892/ijo.2015.3021

\begin{abstract}
Research on carcinogenesis and progress in cancer treatment have reduced mortality of cancer patients. Mortality rates decreased by $1.5 \%$ per year from 2001 through 2010 for most types of cancer in men and women. However, oral cancer is still a significant global health problem since incidence and mortality rates are increasing. Oral cavity cancer is ranked the 8th in men and the 14th in women based on data collected between 2006 and 2010 by the National Institute of Health. Furthermore, an increasing incidence of head and neck neoplasms, particularly the tongue cancer among young adults has been reported recently. It is most likely due to increasing human papillomavirus (HPV) infection or the early start of tobacco and alcohol consumption. Treatment of oral cancer patients is mainly surgical and often leads to esthetic and functional deformities, with severe impact on the quality of life. Thus, novel form of treatments and selection of patients with high and low risk of mortality is of high priority for clinical studies. The expression of proteolytic enzymes in tumor and stromal tissues has been shown to have prognostic significance in many human cancers and inhibiting proteolysis can reduce tumor growth in many in vivo and in vitro models. Plasmin, with its activators and inhibitors are of great importance in many human malignances and collectively are called plasminogen activation system (PAS). In this comprehensive review we examine expression, possible prognostic markers and importance for therapy of the PAS members in oral cancer. Literature review suggests that overexpression of urokinase and its receptor are markers of poor outcome, thus, their inhibition can be explored in oral cancer therapy. Role of plasminogen activator inhibitor (PAI-1) is complex and depends on its concentration. Overexpression of PAI-1 favors angiogenesis, metastasis and poor prognosis, although when applied in very high concentrations it inhibits angiogenesis
\end{abstract}

Correspondence to: Dr Marzena Wyganowska-Świątkowska, Department of Conservative Dentistry and Periodontology, Poznan University of Medical Sciences, Poznań 60-820, Poland

E-mail: marzena.wyganowska@periona.pl

Key words: urokinase, tPA, PAI-1, plasmin, oral cancer and tumor growth, the phenomenon is described as the PAI-1 paradox.

\section{Contents}

1. Introduction

2. Plasminogen activation system

3. Plasminogen activation system in oral cancers

4. Plasminogen activation system as potential therapeutic target in oral cancer

5. Summary

\section{Introduction}

Dynamic research on carcinogenesis and cancer treatment has finally started to reduce mortality of cancer patients. Death rates decreased by $1.5 \%$ per year from 2001 through 2010 for most cancers in men and women for all major racial and ethnic groups (1). Oral cavity cancer is the 8th most common cancer in men and the14th in women based on data collected between 2006 and 2010 by the National Institute of Health (NCI) (1). However, oral cancer is still a significant global health problem since incidence and mortality rates are increasing requiring constant search for novel approaches for treatment. Furthermore, an increasing incidence of head and neck neoplasms, particularly tongue cancer among young adults has been reported recently. It is most likely due to increasing human papillomavirus (HPV) infection or the early start of tobacco and alcohol consumption (2-4).

Meaningful drug designs for therapeutic intervention of oral cancers necessitate an exhaustive understanding of the role of all the factors involved in complicated mechanism of tumor formation and progression. The expression of proteolytic enzymes in tumor and stromal tissues has been shown to have prognostic significance in many human cancers. Mechanisms of action of the individual components have been extensively studied in tumor cells in vitro and in animal models. In several experimental tumor models in animals some degrees of tumor control have been achieved. Specifically, inhibitors of urokinase (uPA) and matrix metalloproteinases (MMP) 
reduce growth or size of cancers (5-7). We review literature on prognostic value of the expression of proteolytic enzymes and mechanism of action of their inhibitors.

\section{Plasminogen activation system}

The plasminogen activation system (PAS) contains the elements defined below. Plasminogen (PLA) is a proenzyme that is cleaved by urokinase plasminogen activator (uPA) or tissue plasminogen activator (tPA). Cleaved PLA becomes an active form called plasmin. Plasmin is a strong proteolytic enzyme able to digest proteins of connective tissue and basement membranes. It is also able to activate other latent proteolytic enzyme, such as procollagenase broadening the spectrum of proteins hydrolyzed. Plasmin plays a fundamental role in tissue remodeling, tumor invasion and development of distant metastasis and angiogenesis (8-10).

$u P A$ and $t P A$ activators. Both uPA and tPA are weak proteolytic enzymes with one known function i.e. activating plasminogen to plasmin. Urokinase is implicated in pericellular proteolysis during tissue remodeling, wound healing, angiogenesis, but tPA mediates intravascular thrombolysis (11-13).

Inhibitors of plasminogen activators. There are few known protein inhibitors of uPA/tPA: PAI-1, PAI-2 and protein nexin. Most relevant appears to be PAI-1 existing as active, non-active-latent and/or cleaved non-active forms. Unique to this serpin protein is the close association between its conformational and functional properties. PAI-1 is a highly specific inhibitor of tPA and UPA, however, it is not a stable protein but converts quickly from active into the latent form, with a halflife of $t_{1 / 2}=2 \mathrm{~h}$. This transmission is associated with insertion of the reactive loop (P4-P10') into the central $\beta$-sheet of the PAI-1 molecule. In such a conformation, P1-P1' and other sites are not accessible for reaction with tPA or uPA (Fig. 1).

PAI-1 has two different functions: i) it is a direct inhibitor of tPA and uPA blocking activation of plasminogen; ii) it binds with the adhesive glycoprotein vitronectin. PAI-1/vitronectin complex acts in tissue remodeling and metastasis. This function is independent of its proteinase inhibitory properties $(6,12-14)$.

$u P A$ receptor. The $\mathrm{UPA}$ receptor ( $\mathrm{UPAR}$ ) is a glycoprotein that binds uPA to the cell surface while uPA maintains its potential to activate plasminogen to plasmin. High numbers of uPA receptors on the surface of cancer cells, if occupied by uPA, enhance the proteolytic activity in their proximity $(6,15,16)$.

\section{Plasminogen activation system in oral cancers}

Urokinase in oral cancers. The ability of solid tumors to invade adjacent tissue and to metastasize depends on the UPA activated plasmin capable of digesting adjacent connective tissue and basement membranes (14). Overexpression of uPA in tumor tissues, as well as in serum, are well documented as prognostic markers of poor outcome in a wide range of malignancies (17). Yet, possible impact of uPA on the prognosis and outcome of an oral cancer was investigated only by a few laboratories.
A

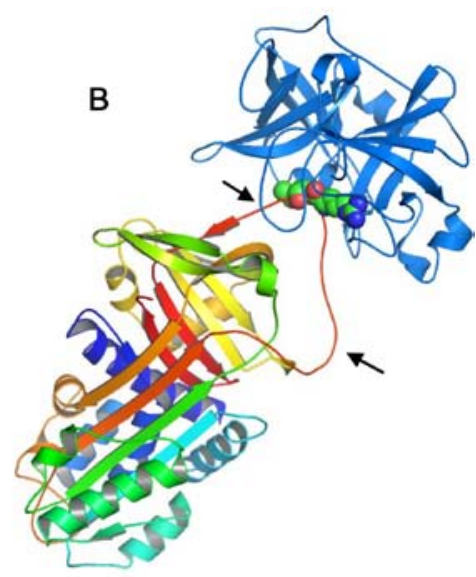

C

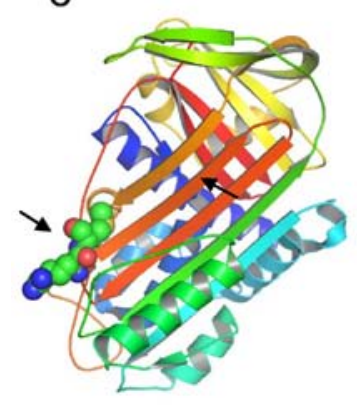

D

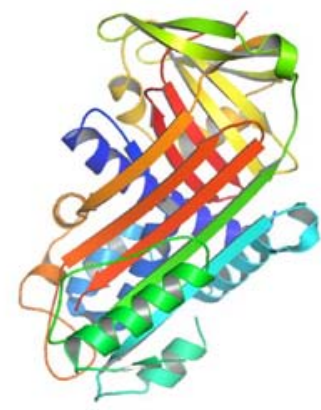

Figure 1. Ribbon model of different forms of PAI-1 in rainbow colors (from blue N-terminus to red C-terminus), Arg 269 and Met 270 of the active site are shown as spheres: carbon in green, nitrogen in blue, oxygen in red, sulfur in yellow, for clarity hydrogens are omitted. (A) Active site of PAI-1 [1b3k] (4); (B) PAI-1 in complex with uPA [3pb1] (3), Arg 269 is inserted into specificity pocket of urokinase. (C) Latent form of PAI-1 [1dvn] (105). (D) Cleaved form is formed while P1-P1' of reactive center bond is cleaved upon complexing with uPA, followed by an insertion of the part of the RCL into $\beta$-sheet A of PAI-1 [3eox] (2). During this conformational transformation, the active site of the urokinase is deformed, consequently uPA is inhibited. Approximate position of reactive center loop of PAI-1 is indicated by arrows where appropriate.

Weng et al (18) investigated if polymorphisms of uPA, that can change expression of urokinase, could have impact on outcome of oral cancer. They investigated 253 patients with oral cancer and 344 healthy controls. Their findings revealed that it was no significant effect of uPA gene on the susceptibility to oral cancer. Duong et al (19) used 3-dimensional (3-D) cell invasion model for oral mucosa fibroblasts and oral cancer cell invasion into the basement membrane and connective tissue stroma. The oral mucosal fibroblasts and cell carcinoma were treated by uPA. They showed that the presence of uPA enhanced cell invasion. Yoshizawa et al (20) studied the relationship between the clinicopathological findings and expression of uPA in oral squamous cell carcinoma (OSCC). They examined 54 cases of OSCC using reverse immuohistochemical techniques. OSCC cases with high uPA level showed the worst survival rate (5-year overall survival rate, 29.4 vs. $77.8 \%$ for low level).

A high expression of extracellular matrix metalloproteinase inducer (EMMPRIN) in cancer tissues has been linked with tumor invasion in cancers of oral cavity. In general the 
EMMPRIN effect has been associated with induction of MMP activity, but it has also been demonstrated that EMMPRIN enhances uPA activity. Lescaille et al (21) investigated OSCC by treating cultured cells with EMMPRIN-enriched membrane vesicles. Urokinase expression was analyzed in cells and tumor tissue by qPCR, immunostaining, and the invasion ability was studied using Boyden chamber assay. They found that OSCC tumors overexpress EMMPRIN and uPA compared to dysplastic lesions. Squamous cell carcinoma (SCC-9) and cell line established from human dysplastic oral mucosa tissue (DOK), showed similar expression pattern. In SCC-9 and DOK cell lines EMMPRIN upregulated uPA and, as expected, MMP-2 and MMP-9. EMMPRIN also significantly increased cell invasion MMP and uPA dependently. It was concluded that the upregulation of uPA by EMMPRIN promotes oral tumor invasion.

Zhang et al (22) investigated the expression of seven biomarkers (among them proteolytic enzymes) of lymphatic spread in OSCC patient tissues. Tissue samples were obtained from 138 patients undergoing tumor resection. Using immunohistochemical staining techniques they found that all biomarker expressions were closely related with lymph node status and clinical stage. Urokinase in cancer tissues was significantly higher than in normal tissue. Also, expression of uPA was higher in metastatic tumor tissues than in non-metastatic tumors. Authors concluded that upregulation of MMP-1, MMP-2 and uPA might predict lymphatic dissemination for OSCC patients at relatively early stage.

tPA in oral cancer. Tissue plasminogen activator has been shown activated in various cancers including oral malignancy. However, it seems that it is not associated with the ability of cancer to metastasize or the prediction of outcome (23-26).

PAI-1 in oral cancer. Similarly to uPA, elevated levels of PAI-1 in tumor tissues are accepted as prognostic markers of poor outcome in a many human cancers (27-32). It was suggested that PAI-1 may be required for effective angiogenesis as well as tumor growth (26,33-35). PAI-1 may also increase tumor growth by way of the inhibition of apoptosis (36). It is paradoxical at first glance, since proteolysis via plasmin, activated by UPA, enhances tumor growth and invasion, while PAI-1 is known to inhibit urokinase. However, effects of PAI-1 on cancer depend on it concentration and thus are not related only to inhibition of proteolysis. PAI-1 binds with high affinity to the N-terminal of vitronectin (VN) to which uPAR also binds, but with lower affinity (37). It was postulated that PAI-1 can free the cells from the extracellular matrix (ECM) (36). At high concentrations, PAI-1 might displace VN from the uPAR-VN complex. Thus, the tumor cell can detach from VN and the ECM, enhancing cell migration and metastasis (38). When cancer cell culture was treated with PAI-1 it inhibited spontaneously inducing apoptosis, that was reversed by antibodies which neutralized active PAI-1 (36). Other mechanisms have been proposed, such as inactivation of caspase-3, upregulation of $\mathrm{Bcl}-2$, c-jun/ERK, Bcl-XL and downregulating Bax and Bcl-X8 after internalization of uPA/uPAR/PAI-1 complex (39). PAI-1 can be proangiogenic or anti-angiogenic depending on its concentration $(35,40,41)$. In experimental animal tumor models, physiological levels of PAI-1 are needed for vascularization of tumors, but in PAI-1 knockout (PAI-1-/-) mice angiogenesis was decreased. Increased levels of PAI-1 by adenoviral PAI-1 gene transfer to cancer cells increases tumor angiogenesis (42). Further increase of PAI-1 levels reduces angiogenesis as it was shown in chicken chorioallantoic membrane angiogenesis model and some animal models requiring supraphysiological levels of PAI-1. The high concentration of PAI-1 inhibits uPA on the angiogenic vessel preventing its progression into the tumor body $(35,43-45)$.

Weng et al (18) investigated whether polymorphisms of PAI-1 associated with the risk of developing clinical stage III or IV cancer and lymph node metastasis. Large group of patients (253 patients with oral cancer and 344 healthy controls) were analyzed by polymerase chain reactionrestriction polymorphism. It was found that patients with oral cancer with one or more $5 \mathrm{G}$ allele of PAI-1 gene have a lower risk of developing clinical stage III or IV and lymph node metastasis in comparison to those with $4 \mathrm{G} / 4 \mathrm{G}$ homozygotes. The $4 \mathrm{G}$ allele of $4 \mathrm{G} / 5 \mathrm{G}$ insertion/deletion polymorphism in the promoter region $675 \mathrm{bp}$, upstream from the transcription start sequence of the PAI-1 gene, produces higher plasma PAI-1 levels in humans (46). Similar result was found by Vairaktaris et al (47). They suggest that the $4 \mathrm{G}$ allele results in higher PAI-1 expression and is a contributing factor in early stages of oral carcinogenesis. They reported also that increased PAI-1 stimulates development of early stages of OSCC via increase of cell detachment that favors metastasis. However, in advanced OSCC PAI-1 might delay tumor progression by inhibiting vascularization.

UPAR in oral cancer. Strong correlations between poor prognosis in numerous malignances and levels of uPA and uPAR have been reported (48-50). Nozaki et al (51) concluded that UPAR is needed for invasion and metastasis of highly malignant oral cancer cells (OSC-19). Moreover, treatments of these cells with antisense oligonucleotides that target uPAR dramatically reduced uPAR mRNA expression. Consequently, pretreatment with oligonucleotides inhibited progression of OSC-19 cells in animal experimental models. They suggested that UPAR is a promising therapeutic target in oral cancer.

Yoshizawa et al (20) investigated the binding of uPA to UPAR in relation to cancer invasion and metastasis in OSCC patients. Using immunohistochemical techniques to assess the expression of UPA, uPAR in 54 cases and in six cell lines derived from OSCC using reverse transcriptase-polymerase chain reaction (RT-PCR), they showed a positive correlation with potential of cancer invasion. Specifically, tumors showing elevated levels of $\mathrm{uPA}^{+} / \mathrm{uPAR}^{+} /$maspin $^{-}$metastasized more frequently and had the worst survival rate (5-year survival rate, $29 \%$ ). Tumors with an expression of uPA- $/ \mathrm{uPAR}^{-} / \mathrm{maspin}^{+}$, exhibited the most favorable 5-year survival rate of $78 \%$. Similar results were observed in expression of $\mathrm{uPA}^{+} / \mathrm{uPAR}^{+}$ in cells with stronger invasive potential than in the cells lines derived from the lower grades. Also, lower expression of maspin was observed in the cell lines derived from high grades of OSCC. It seems that levels of UPA, uPAR and maspin may be useful prognostic markers in OSCC patients (20). Role of maspin in oral carcinoma is not understood. Maspin (mammary serine protease inhibitor) protein belongs to the serpin (serine protease inhibitor) superfamily $(52,53)$. 
The exact molecular function of maspin in carcinogenesis is currently unknown $(54,55)$.

In a different study (56) expression of UPAR in the malignant OSCC in 34 the primary oral cancers were examined immunohistochemically. The urokinase receptor expression was detected in $29.4 \%$ cases. UPAR expression correlated with the mode of invasion. In highly invasive tumors both UPA and UPAR were positive. Moreover, they found that $\mathrm{uPA}^{+} / \mathrm{uPAR}^{+} / \mathrm{PAI}-2^{-}$cases almost always showed secondary lymph node metastasis. They concluded that the PAS plays a major role in the invasion and metastasis of OSCC, and might be a powerful prognostic marker (56). This was the only literature found describing PAI-2 involvement in oral cancers.

Shi et al (57) examined the contribution of UPAR to protein expression in a human OSCC using tissue microarray. Overexpression of UPAR relative to vector control cells revealed a significant correlation between UPAR and p130cas expression. They suggested that protein tyrosine kinase c-Src was responsible for the phosphorylation of p130cas in response to uPAR high expression. Also, the Rho family GTPase Cdc42, but not Rac1, were activated, suggesting a pathway leading to actin reorganization, filopodial protrusion and enhanced motility in UPAR overexpressing OSCC. These results suggest additional mechanism, different than participation of uPAR in proteolysis, could modulate OSCC invasive activity.

\section{Plasminogen activation system as potential therapeutic target in oral cancer}

Inhibition of $u P A$ in oral cancer. Despite existing highly specific uPA inhibitors such as inhibitor CJ-463 (benzylsulfonyl-D-Ser-Ser-4-amidinobenzylamide) $(58,59)$, benzamidine, p-benzamidine, amiloride (60-62), 6-substituted 2-naphthamidine inhibitors (63), EGCG $(64,65)$, PAI-1 $(35,66)$, there has been no attempt to therapeutically inhibit urokinase in oral cancers by binding such inhibitors to its active site, rather almost exclusively research was done on biologicals (plant derived products).

Quercetin is a flavonol found in many fruits, vegetables, leaves and grains $(67,68)$. Quercetin has been shown to have a wide range of pharmacological properties, including anticancer activities. Lai et al (69) found that quercetin significantly reduced expression of several enzymes (COX-2, MMP-2, -7, $-9,-10$, VEGF and others) including uPA in human oral cancer cell (SAS) culture after 12- and 24-h treatment.

Curcumin is the principal curcuminoid of turmeric, a widely used Indian spice. Turmeric contains two other curcuminoids: desmethoxycurcumin and bis-desmethoxycurcumin. Curcumin exists in several tautomeric forms, with enol form being more energetically stable (70). Published literature provides many examples describing use of curcumin in therapy including for malignancy $(71,72)$. Zhen et al $(73)$ investigated effects of curcumin on the activation of EGFR and its downstream signaling molecules in SCC-25 oral cell invasion. They showed that curcumin inhibited SCC-25 cell proliferation and inhibited SCC-25 cell invasion by downregulation of UPA and UPAR, MMP-2 and MMP-9 expression.

Green tea polyphenols are cancer chemopreventive and cancer treatment agents studied for many years.
Epigallocatechin-3-gallate (EGCG), which is the most abundant polyphenol in green tea, has been proven to suppress many cancers in animal and epidemiological studies (74-76). Human oral cancer cell line OC2 cells were treated with EGCG resulted in a dose-dependent inhibition of the invasion and migration of OC2 cells. Ho et al (77) performed gelatin zymography and casein zymography to evaluate the impact of EGCG on MMP-2, - 9 and UPA secretion by OC 2 cells. EGCG decreased the expression of MMP-2, -9 and UPA concentration-dependently. Authors suggested that EGCG might inhibit the invasion and migration of human oral cancer cells because of the decreased productions of proteinases.

Balcalein is a flavonoid, originally isolated from the roots of Scutellaria baicalensis and Scutellaria lateriflora with anticancer activity (78-80). Apigenin, present in many plants, is a natural product belonging to the flavone class, structurally similar to balcalein and 4',5,7-trihydroxyflavanone. These flavones were reported to possess anticancer activity as well (81). Yang et al (82) treated cultured OSCC cells with 5,6,7-trihydroxyflavanone (baicalein), 7-hydroxyflavanone (apigenin) and 4',5,7-trihydroxyflavanone. They reported that flavone treatment of cultured cells resulted in decrease of uPA, and MMP-2 as measured by zymography and western blot analysis in a concentration-dependent manner. Furthermore, in chorioallantoic membrane assay flavones reduced blood vessel formation.

Inhibition of PAI-1 in oral cancer. PAI-1 is playing an important role in many pathological processes such as fibrosis, thromboembolic diseases, atherosclerosis and cancer. The inactivation of PAI-1 by small organic molecules or peptides has been observed in in vitro and in vivo models. PAI-1 has been postulated as a potential therapeutic target for pathological conditions including cancer $(6,83,84)$.

PAI-1 can be inhibited either by antibody or small molecule inhibitors. The monoclonal antibodies can inactivate PAI-1 most effectively by preventing formation of the Michaelis complex between substrate (UPA) and PAI-1. Some other mechanisms were also postulated such as: acceleration the transition from active to the latent form or by inducing turnover of the PAI-1 protease complex as a substrate (85-88).

Several small molecule inhibitors have been found to inhibit PAI-1, but the mechanisms seem to be different. For example AR-H029953XX (89) and PAI-039 (90) inhibitors bind to the hydrophobic cleft region around $\alpha$-helices $\mathrm{D}$ and E and $\beta$-strand 1A (Fig. 2). This part of PAI-1 molecule acts as a flexible joint when $\beta$-sheet $A$ opens and the reactive center loop of PAI-1 is inserted as $\beta$-strand 4A. In that way inhibition of PAI-1 occurs not by prevention of the interaction between PAI-1 and the substrate, but by inhibiting the formation of a stable covalent complex, that must be created to act on uPA or tPA. A different binding site was proposed for PAI-749 small molecule inhibitor that is blocking formation of the initial Michaelis complex between PAI-1 and tPA or uPA (91). Yang et al (82) treating cultured OSCC cells with 4',5,7-trihydroxyflavanone and 7-hydroxyflavanone found that these inhibitors downregulate expression of PAI-1. Surprisingly, treatment with 5,6,7-trihydroxyflavanone increased PAI-1 expression. These examples do not include 
A
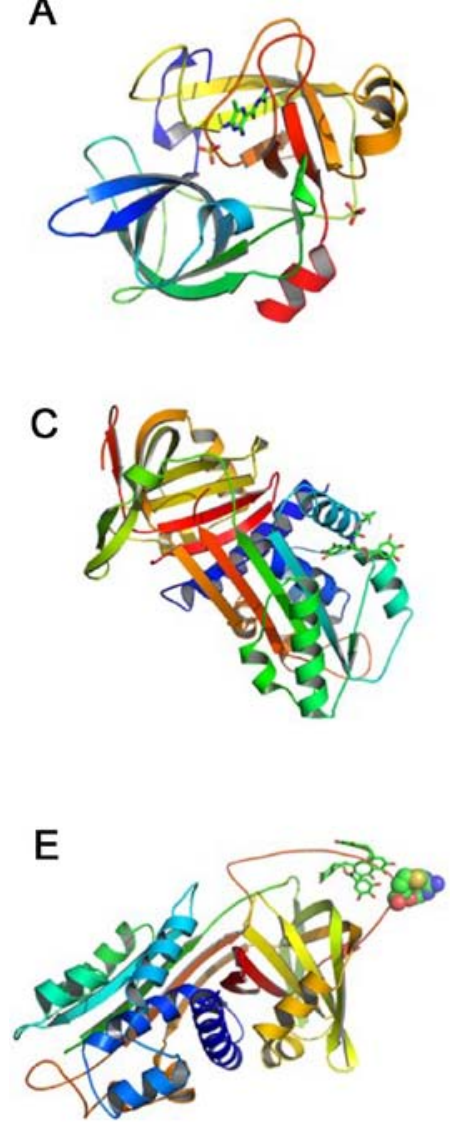

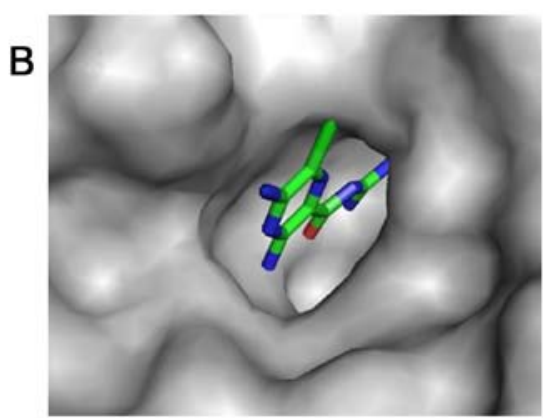

D

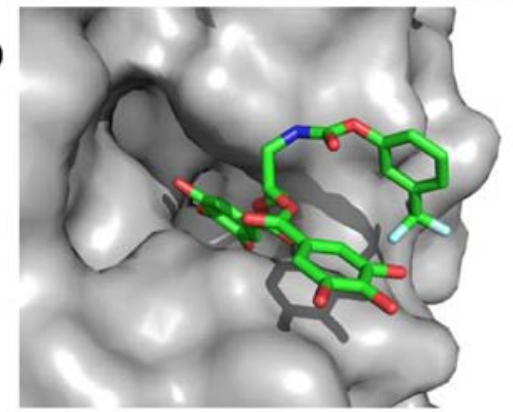

$\mathrm{F}$

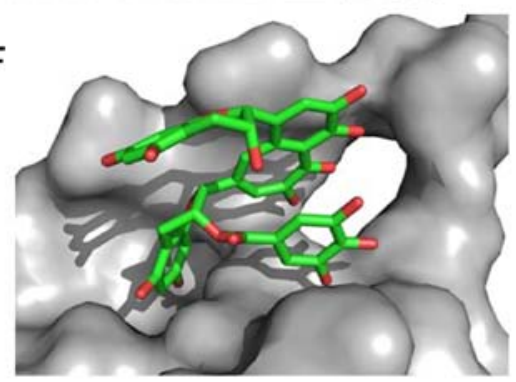

Figure 2. Inhibition of uPA and PAI-1 by small molecular chemicals. (A) Ribbon model of uPA in complex with amiloride [1f5k] (106). (B) Surface of uPA and stick model of amiloride in specificity pocket of uPA. All known inhibitors of uPA bind in this part of the urokinase. Inactivation of PAI-1 is more complex. It can bind to the hydrophobic cleft region around $\alpha$-helices $\mathrm{D}$ and $\mathrm{E}$ as shown on $\mathrm{C}$ and $\mathrm{D}$ or in the proximity of active site of PAI-1 as shown in E and $\mathrm{F}$ (CDE-096, a carbamoyl derivative of a synthetic digalloyl polyphenol compound) [4g8r] (107). Inhibitor of PAI-1 can bind in the proximity of its active site [theaflavin] $(86,92)$. Proteins are shown in rainbow colors, protein surface in gray, inhibitors are presented as stick model, carbons in green, oxygen in red, nitrogen in blue, fluorine in light blue, hydrogens are omitted for clarity.

all known inhibitors but rather are intended to illustrate complexity of PAI-1 inactivation.

Our previous study revealed that a black tea extract (containing mostly theaflavins) as well as the isolated theaflavins (theaflavin-3'-gallate, theaflavin-3,3'-digallate), were potent inhibitors of PAI-1 while the other two i.e., theaflavin and theaflavin-3-gallate did not show inhibitory activity (92). From computer molecular modeling of complex formation, we found that the most likely place of binding would be in the proximity of Arg346-Met347 (P1, P1') i.e. at the active site of PAI-1 (86,92).

We have found no literature on therapeutic use of PAI-1 inhibitors in oral cancer. However, Zhang et al (93) summarized evidence on associations between black tea consumption and oral cancer by analyzing 57 articles based on 87 datasets containing $\sim 50,000$ cases. In general, high tea consumption reduced risk of oral cancer and dose response meta-analysis indicated that even an increase in tea consumption reduce risk of oral cancer. They also reported that there was no effect on gastric, rectal, colon, lung, pancreatic, liver, breast, prostate, ovarian or bladder cancers.

Lee et al (94) studied bioavailability of theaflavins after thoroughly rinsing brewed black tea ( $2 \mathrm{~g}$ of black tea leaves in
$100 \mathrm{ml})$ in the mouth for $2-5 \mathrm{~min}$. They found that high concentrations of theaflavins $\left(\mathrm{C}_{\max }=0.6-1.8 \mu \mathrm{M}\right)$ were observed in saliva $1 \mathrm{~h}$ after washing. They concluded that these results indicated that using black tea could be a convenient, slowrelease source of theaflavins in the prevention of oral cancer and dental caries.

Therefore, it is plausible that anticancer activity of theaflavins could be related to inhibition of PAI-1. However, many mechanisms of black tea action have been proposed for prevention of the cancer formation and growth. These include the modulation of signal transduction pathways limiting the inhibition of cell proliferation and transformation, initiation of apoptosis of cancer cells, and inhibition of tumor invasion and angiogenesis (95). Because of this multiplicity of action of black tea polyphenols, demonstration that anticancer activity of theaflavins is related to PAI-1 inactivation need to be better evaluated and verified in the future.

Inhibition of $U P A R$ in oral cancer. High expression of urokinase plasminogen activator receptor (UPAR) is involved in progression and metastasis of oral cancer $(51,96,97)$. One of the possibilities of inactivation of UPAR is silencing this gene by RNA interference (siRNA). Liang et al (98) introduced 


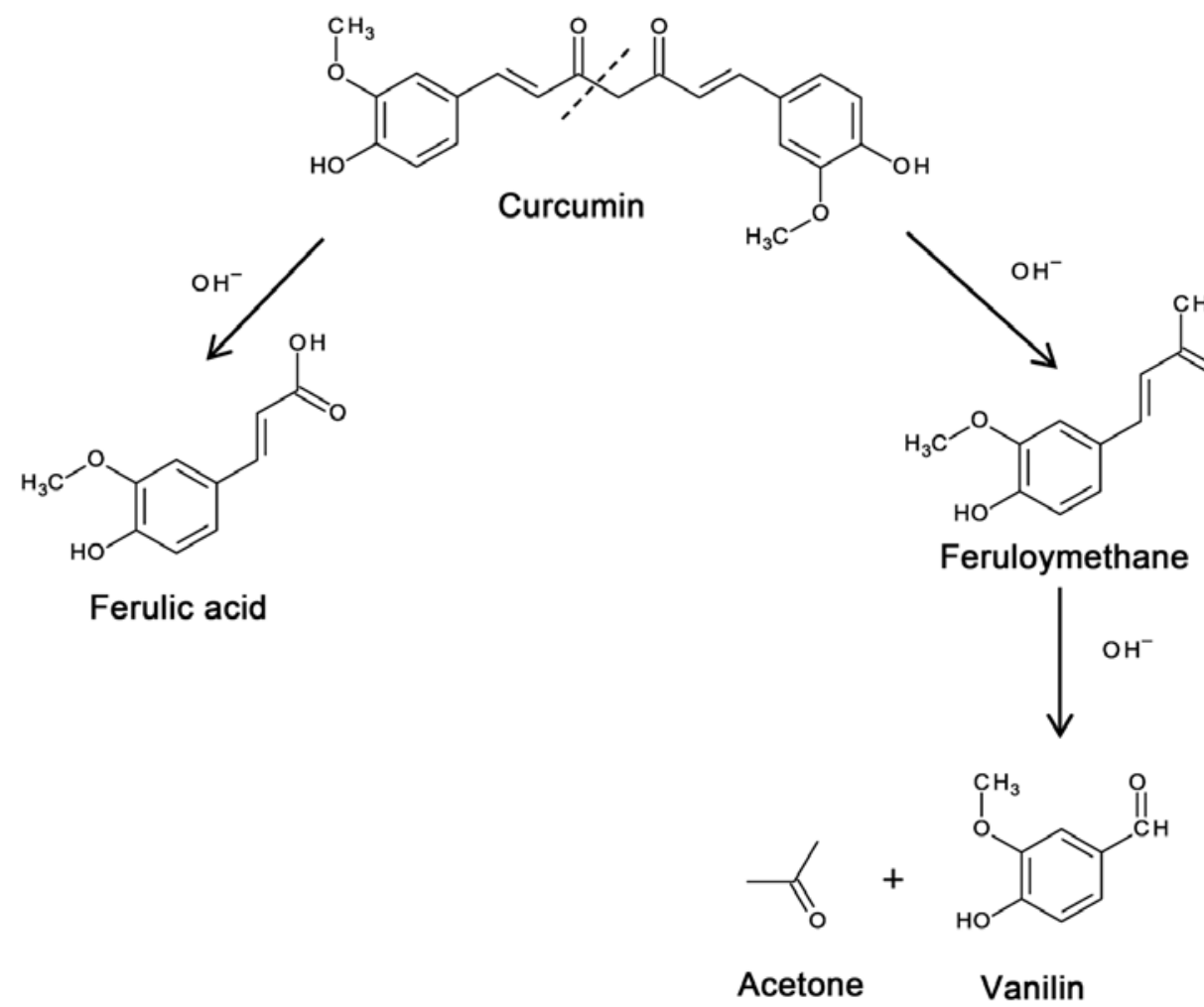

Figure 3. Degradation of curcumin incubated in phosphate buffer $\mathrm{pH} 7.2$ and in $37^{\circ} \mathrm{C}(104,108)$.

siRNA to downregulate the expression of UPAR in the highly malignant OSCC cells and demonstrated that siRNA leads to the efficient inhibition of endogenous UPAR mRNA as well as protein expression. Consequently, silencing of uPAR resulted in an impressive reduction of cell proliferation, adhesion, migration and invasion in vitro. They conclude that RNAi-directed targeting of UPAR can be used in therapy of oral cancer, especially in preventing cancer cell invasion and metastasis. Similar approach was used by Nozaki et al (51). They found that uPAR is required for invasion and metastasis of highly malignant oral cancer cells (OSC-19). When cells were treated with antisense oligonucleotide targeting uPAR a dramatic reduction of UPAR mRNA was observed. Also, cells pretreated with antisense oligonucleotide or siRNA targeting UPAR, reduce progression of OSC-19 cells in vitro.

Inhibition of epidermal growth factor receptor (EGFR) is a molecular target in anticancer therapies. Curcumin is a nonespecific inhibitor of EGFR and reduces growth, invasion and metastasis in some cancer cells. Zhen et al (73) investigated whether curcumin would influence proliferation and invasion in SCC-25 cell line. They also explored the effect of curcumin on the activition of EGFR and its downstream signaling molecules Akt, ERK1/2 and STAT3. Furthermore, they examined the inhibition effect of curcumin on EGF-induced EGFR phosphorylation and SCC-25 cell invasion. Curcumin inhibited SCC-25 cells proliferation and induced G2/M phase arrest, and cell invasion, in a dose-dependent manner. They also observed downregulation of UPAR and other proteins such as: MMP-2, MMP-9 and uPA. The authors suggested that curcumin reduced SCC-25 uPAR expression most likely by inhibiting the phosphorylation of EGFR and EGFR downstream signaling molecules Akt, ERK1/2 and STAT3.

\section{Summary}

Further progress regarding the application of plasminogen activation system as a therapeutic target and prognostic marker in oral cancer will depend not only on understanding of the role of each member in carcinogenesis but also on interaction between them (99). For example, assessment of net proteolytic balance is needed instead of simple statement that some elements are overexpressed. Not only uPA/PAI-1 balance should be measured but also other proteolytic enzymes (MMP-2, -9) involved in invasion and metastasis should be quantified. Another very important factor is expression of PAI-1 in oral cancer, it can exist in three distinct forms. It is essential to measure each PAI-1 form since active, latent and cleaved variety have completely different effects on inhibition of urokinase driven activation of plasminogen, but they might play a role in cell signaling. Our understanding of cell invasion and metastases of oral cancer cells by mechanisms other than proteolysis is far from complete and should be investigated further.

In addition to age, gender and ethnicity could be the differentiating factors at least in some cases of cancer formation and progression (100). For example in the Supplementation in Vitamins and Mineral Antioxidants Study (SU.VI.MAX) 12,741 French adults (7,713 women and 5,028 men) were given ascorbic acid $(120 \mathrm{mg})$, vitamin $\mathrm{E}(30 \mathrm{mg}), \beta$-carotene $(6 \mathrm{mg})$, selenium $(100 \mu \mathrm{g})$ and zinc $(20 \mathrm{mg})$, or placebo daily for a follow-up time of 7.5 years. Supplementation reduced total cancer rate and total cancer death in men but in women an increase of skin cancer including melanoma was observed (101). It was reported also that functional polymorphisms of EGFR is a prognostic markers in colon cancer but has opposite 
prognostic consequences in males and females (102). It has been shown also that sex hormone receptors are expressed in some cancers and play role in gene expression involved in carcinogenesis (103). Thus, it is important to attract the attention toward the impending role of sex hormones in oral carcinogenesis in future research. Furthermore, cancer risk for women taking female hormone therapy should be investigated.

Use of biologicals to alter gene expression or to inhibit enzymes in humans is relatively easy to convince ethics committees, especially if these are constituents of food. However, one should keep in mind that their bioavailability could be biased since they could be degraded/transformed and thus not detected or difficult to follow, as can be seen in case of curcumin. Curcumin application could be beneficial albeit it is not stable under different conditions. For example: it is degraded in aqueous solution where, $\sim 90 \%$ decomposed within $30 \mathrm{~min}\left(0.1 \mathrm{~mol} / 1\right.$ phosphate buffer, $\mathrm{pH} 7.2$ at $\left.37^{\circ} \mathrm{C}\right)$ to the bioactive compounds such as ferulic acid, feruloylmethane and vanillin (Fig. 3) (104) and we cannot define which of all of them, or combination of some, are responsible for the benefits. Use of specific and stable compound could be more beneficial in treatment of oral cancer and prediction of its outcome.

\section{Acknowledgements}

The present review was supported in part by grants from the Poznan Medical University, the Frank Stranahan Endowed Chair and the Children Miracle Network.

\section{References}

1. Edwards BK, Noone AM, Mariotto AB, Simard EP, Boscoe FP, Henley SJ, Jemal A, Cho H, Anderson RN, Kohler BA, et al: Annual Report to the Nation on the status of cancer, 1975-2010, featuring prevalence of comorbidity and impact on survival among persons with lung, colorectal, breast, or prostate cancer. Cancer 120: 1290-1314, 2014

2. Nemoto RP, Victorino AA, Pessoa GB, da Cunha LL, da Silva JA, Kanda JL and Matos LL: Oral cancer preventive campaigns: are we reaching the real target? Braz J Otorhinolaryngol 81: 44-49, 2015.

3. Toporcov TN, Znaor A, Zhang ZF, Yu GP, Winn DM, Wei Q, Vilensky M, Vaughan T, Thomson P, Talamini R, et al: Risk factors for head and neck cancer in young adults: A pooled analysis in the INHANCE consortium. Int J Epidemiol 44: 169-185, 2015.

4. Walsh T, Liu JL, Brocklehurst P, Glenny AM, Lingen M, Kerr AR, Ogden G, Warnakulasuriya S and Scully C: Clinical assessment to screen for the detection of oral cavity cancer and potentially malignant disorders in apparently healthy adults. Cochrane Database Syst Rev 11: CD010173, 2013.

5. Chorostowska-Wynimko J, Swiercz R, Skrzypczak-Jankun E, Wojtowicz A, Selman SH and Jankun J: A novel form of the plasminogen activator inhibitor created by cysteine mutations extends its half-life: Relevance to cancer and angiogenesis. Mol Cancer Ther 2: 19-28, 2003.

6. Jankun J and Skrzypczak-Jankun E: Yin and yang of the plasminogen activator inhibitor. Pol Arch Med Wewn 119: 410-417, 2009.

7. Lein M, Jung K, Ortel B, Stephan C, Rothaug W, Juchem R, Johannsen M, Deger S, Schnorr D, Loening S, et al: The new synthetic matrix metalloproteinase inhibitor (Roche 28-2653) reduces tumor growth and prolongs survival in a prostate cancer standard rat model. Oncogene 21: 2089-2096, 2002.

8. Al-Horani RA: Serpin regulation of fibrinolytic system: Implications for therapeutic applications in cardiovascular diseases. Cardiovasc Hematol Agents Med Chem 12: 91-125, 2014.
9. Iishi H, Tatsuta M, Baba M, Yano H, Uehara $\mathrm{H}$ and Nakaizumi A: Suppression by amiloride of bombesin-enhanced peritoneal metastasis of intestinal adenocarcinomas induced by azoxymethane. Int J Cancer 63: 716-719, 1995.

10. Wyganowska-Świątkowska M, Surdacka A, SkrzypczakJankun E and Jankun J: The plasminogen activation system in periodontal tissue (Review). Int J Mol Med 33: 763-768, 2014.

11. Jankun $\mathbf{J}$ and Skrzypczak-Jankun E: Plasminogen activator inhibitor with very long half-life (VLHL PAI-1) can reduce bleeding in PAI-1-deficient patients. Cardiovasc Hematol Disord Drug Targets 13: 144-150, 2013.

12. Fortenberry YM: Plasminogen activator inhibitor-1 inhibitors: a patent review (2006-present). Expert Opin Ther Pat 23: 801-815, 2013.

13. Ghosh AK and Vaughan DE: PAI-1 in tissue fibrosis. J Cell Physiol 227: 493-507, 2012.

14. Lindberg P, Larsson A and Nielsen BS: Expression of plasminogen activator inhibitor-1, urokinase receptor and laminin gamma-2 chain is an early coordinated event in incipient oral squamous cell carcinoma. Int J Cancer 118: 2948-2956, 2006.

15. Stewart CE and Sayers I: Urokinase receptor orchestrates the plasminogen system in airway epithelial cell function. Lung 191: 215-225, 2013.

16. Tang $L$ and Han $X$ : The urokinase plasminogen activator system in breast cancer invasion and metastasis. Biomed Pharmacother 67: 179-182, 2013.

17. Gershtein ES and Kushlinskii NE: Clinical prospects of tumorassociated proteases and their tissue inhibitors investigation in oncologic patient. Vestn Ross Akad Med Nauk pp16-27, 2013 (In Russian).

18. Weng CJ, Lin CW, Chung TT, Tsai CM, Chen MK and Yang SF: Impact of uPA system gene polymorphisms on the susceptibility of environmental factors to carcinogenesis and the development of clinicopathology of oral cancer. Ann Surg Oncol 18: 805-812, 2011.

19. Duong HS, Le AD, Zhang Q and Messadi DV: A novel 3-dimensional culture system as an in vitro model for studying oral cancer cell invasion. Int J Exp Pathol 86: 365-374, 2005.

20. Yoshizawa K, Nozaki S, Kitahara H, Kato K, Noguchi N, Kawashiri S and Yamamoto E: Expression of urokinase-type plasminogen activator/urokinase-type plasminogen activator receptor and maspin in oral squamous cell carcinoma: Association with mode of invasion and clinicopathological factors. Oncol Rep 26: 1555-1560, 2011

21. Lescaille G, Menashi S, Cavelier-Balloy B, Khayati F, Quemener C, Podgorniak MP, Naïmi B, Calvo F, Lebbe C and Mourah S: EMMPRIN/CD147 up-regulates urokinase-type plasminogen activator: Implications in oral tumor progression. BMC Cancer 12: 115, 2012.

22. Zhang Z, Pan J, Li L, Wang Z, Xiao W and Li N: Survey of risk factors contributed to lymphatic metastasis in patients with oral tongue cancer by immunohistochemistry. J Oral Pathol Med 40: 127-134, 2011.

23. Curino A, Patel V, Nielsen BS, Iskander AJ, Ensley JF, Yoo GH, Holsinger FC, Myers JN, El-Nagaar A, Kellman RM, et al: Detection of plasminogen activators in oral cancer by laser capture microdissection combined with zymography. Oral Oncol 40: 1026-1032, 2004.

24. Gaarenstroom KN, Kenter GG, Bonfrer JM, Korse CM, Van de Vijver MJ, Fleuren GJ and Trimbos JB: Can initial serum cyfra 21-1, SCC antigen, and TPA levels in squamous cell cervical cancer predict lymph node metastases or prognosis? Gynecol Oncol 77: 164-170, 2000.

25. Jankun J, Maher VM and McCormick JJ: Malignant transformation of human fibroblasts correlates with increased activity of receptor-bound plasminogen activator. Cancer Res 51: 1221-1226, 1991.

26. Jankun J, Merrick HW and Goldblatt PJ: Expression and localization of elements of the plasminogen activation system in benign breast disease and breast cancers. J Cell Biochem 53: 135-144, 1993.

27. Zubac DP, Wentzel-Larsen T, Seidal T and Bostad L: Type 1 plasminogen activator inhibitor (PAI-1) in clear cell renal cell carcinoma (CCRCC) and its impact on angiogenesis, progression and patient survival after radical nephrectomy. BMC Urol 10: 20, 2010.

28. Harbeck N, Schmitt M, Paepke S, Allgayer H and Kates RE: Tumor-associated proteolytic factors uPA and PAI-1: Critical appraisal of their clinical relevance in breast cancer and their integration into decision-support algorithms. Crit Rev Clin Lab Sci 44: 179-201, 2007. 
29. Schrohl AS, Holten-Andersen MN, Peters HA, Look MP, Meijer-van Gelder ME, Klijn JG, Brünner N and Foekens JA: Tumor tissue levels of tissue inhibitor of metalloproteinase- 1 as a prognostic marker in primary breast cancer. Clin Cancer Res 10: 2289-2298, 2004.

30. Borstnar S, Vrhovec I, Svetic B and Cufer T: Prognostic value of the urokinase-type plasminogen activator, and its inhibitors and receptor in breast cancer patients. Clin Breast Cancer 3: 138-146, 2002.

31. Grøndahl-Hansen J, Christensen IJ, Briand P, Pappot H, Mouridsen HT, Blichert-Toft M, Danø $\mathrm{K}$ and Brünner N: Plasminogen activator inhibitor type 1 in cytosolic tumor extracts predicts prognosis in low-risk breast cancer patients. Clin Cancer Res 3: 233-239, 1997.

32. Duggan C, Maguire T, McDermott E, O'Higgins N, Fennelly JJ and Duffy MJ: Urokinase plasminogen activator and urokinase plasminogen activator receptor in breast cancer. Int J Cancer 61: 597-600, 1995

33. McMahon B and Kwaan HC: The plasminogen activator system and cancer. Pathophysiol Haemost Thromb 36: 184-194, 2008.

34. McMahon GA, Petitclerc E, Stefansson S, Smith E, Wong MK, Westrick RJ, Ginsburg D, Brooks PC and Lawrence DA: Plasminogen activator inhibitor-1 regulates tumor growth and angiogenesis. J Biol Chem 276: 33964-33968, 2001.

35. Swiercz R, Keck RW, Skrzypczak-Jankun E, Selman SH and Jankun J: Recombinant PAI-1 inhibits angiogenesis and reduces size of LNCaP prostate cancer xenografts in SCID mice. Oncol Rep 8: 463-470, 2001.

36. Kwaan HC, Mazar AP and McMahon BJ: The apparent uPA/ PAI-1 paradox in cancer: More than meets the eye. Semin Thromb Hemost 39: 382-391, 2013.

37. Okumura Y, Kamikubo Y, Curriden SA, Wang J, Kiwada T, Futaki S, Kitagawa K and Loskutoff DJ: Kinetic analysis of the interaction between vitronectin and the urokinase receptor. J Biol Chem 277: 9395-9404, 2002.

38. Czekay RP, Aertgeerts K, Curriden SA and Loskutoff DJ: Plasminogen activator inhibitor-1 detaches cells from extracellular matrices by inactivating integrins. J Cell Biol 160: 781-791, 2003.

39. Balsara RD and Ploplis VA: Plasminogen activator inhibitor-1: The double-edged sword in apoptosis. Thromb Haemost 100: 1029-1036, 2008.

40. Devy L, Blacher S, Grignet-Debrus C, Bajou K, Masson V, Gerard RD, Gils A, Carmeliet G, Carmeliet P, Declerck PJ, et al: The pro- or antiangiogenic effect of plasminogen activator inhibitor 1 is dose dependent. FASEB J 16: 147-154, 2002.

41. Lambert V, Munaut C, Carmeliet P, Gerard RD, Declerck PJ, Gils A, Claes C, Foidart JM, Noël A and Rakic JM: Dosedependent modulation of choroidal neovascularization by plasminogen activator inhibitor type I: Implications for clinical trials. Invest Ophthalmol Vis Sci 44: 2791-2797, 2003.

42. Bajou K, Masson V, Gerard RD, Schmitt PM, Albert V, Praus M, Lund LR, Frandsen TL, Brunner N, Dano K, et al: The plasminogen activator inhibitor PAI-1 controls in vivo tumor vascularization by interaction with proteases, not vitronectin. Implications for antiangiogenic strategies. J Cell Biol 152: $777-784,2001$.

43. Nishioka N, Matsuoka T, Yashiro M, Hirakawa K, Olden K and Roberts JD: Plasminogen activator inhibitor 1 RNAi suppresses gastric cancer metastasis in vivo. Cancer Sci 103: 228-232, 2012

44. Stefansson S, McMahon GA, Petitclerc E and Lawrence DA Plasminogen activator inhibitor-1 in tumor growth, angiogenesis and vascular remodeling. Curr Pharm Des 9: 1545-1564, 2003.

45. Zheng D, Chen H, Davids J, Bryant M and Lucas A: Serpins for diagnosis and therapy in cancer. Cardiovasc Hematol Disord Drug Targets 13: 123-132, 2013.

46. Kohler HP and Grant PJ: Plasminogen-activator inhibitor type 1 and coronary artery disease. N Engl J Med 342: 1792-1801, 2000

47. Vairaktaris E, Yapijakis C, Serefoglou Z, Vylliotis A, Ries J, Nkenke E, Wiltfang J, Derka S, Vassiliou S, Springer I, et al: Plasminogen activator inhibitor-1 polymorphism is associated with increased risk for oral cancer. Oral Oncol 42: 888-892, 2006.

48. Grunnet M, Christensen IJ, Lassen U, Jensen LH, Lydolph M, Lund IK, Thurison T, Høyer-Hansen G and Mau-Sørensen M: Prognostic significance of circulating intact and cleaved forms of urokinase plasminogen activator receptor in inoperable chemotherapy treated cholangiocarcinoma patients. Clin Biochem 47: 599-604, 2014
49. Illemann M, Laerum OD, Hasselby JP, Thurison T, HøyerHansen G, Nielsen HJ and Christensen IJ; Danish Study Group on Early Detection of Colorectal Cancer: Urokinase-type plasminogen activator receptor (uPAR) on tumor-associated macrophages is a marker of poor prognosis in colorectal cancer. Cancer Med 3: 855-864, 2014.

50. Thurison T, Christensen IJ, Lund IK, Nielsen HJ and HoyerHansen G: Circulating intact and cleaved forms of the urokinase-type plasminogen activator receptor: biological variation, reference intervals and clinical useful cut-points. Clin Chim Acta 439: 84-90, 2015.

51. Nozaki S, Endo Y, Nakahara H, Yoshizawa K, Hashiba Y, Kawashiri S, Tanaka A, Nakagawa K, Matsuoka Y, Kogo M, et al: Inhibition of invasion and metastasis in oral cancer by targeting urokinase-type plasminogen activator receptor. Oral Oncol 41: 971-977, 2005.

52. Sager R, Sheng S, Pemberton P and Hendrix MJ: Maspin. A tumor suppressing serpin. Adv Exp Med Biol 425: 77-88, 1997.

53. Sager R, Sheng S, Pemberton $P$ and Hendrix MJ: Maspin: A tumor suppressing serpin. Curr Top Microbiol Immunol 213: 51-64, 1996.

54. Chen EI and Yates JR III: Maspin and tumor metastasis. IUBMB Life 58: 25-29, 2006.

55. Teoh SS, Vieusseux J, Prakash M, Berkowicz S, Luu J, Bird CH, Law RH, Rosado C, Price JT, Whisstock JC, et al: Maspin is not required for embryonic development or tumour suppression. Nat Commun 5: 3164, 2014

56. Nozaki S, Endo Y, Kawashiri S, Nakagawa K, Yamamoto E, Yonemura $Y$ and Sasaki T: Immunohistochemical localization of a urokinase-type plasminogen activator system in squamous cell carcinoma of the oral cavity: Association with mode of invasion and lymph node metastasis. Oral Oncol 34: 58-62, 1998.

57. Shi Z, Liu Y, Johnson JJ and Stack MS: Urinary-type plasminogen activator receptor (UPAR) modulates oral cancer cell behavior with alteration in p130cas. Mol Cell Biochem 357: 151-161, 2011

58. Henneke I, Greschus S, Savai R, Korfei M, Markart P, Mahavadi P, Schermuly RT, Wygrecka M, Stürzebecher J, Seeger W, et al: Inhibition of urokinase activity reduces primary tumor growth and metastasis formation in a murine lung carcinoma model. Am J Respir Crit Care Med 181: 611-619, 2010.

59. Schweinitz A, Steinmetzer T, Banke IJ, Arlt MJ, Stürzebecher A, Schuster O, Geissler A, Giersiefen H, Zeslawska E, Jacob U, et al: Design of novel and selective inhibitors of urokinase-type plasminogen activator with improved pharmacokinetic properties for use as antimetastatic agents. J Biol Chem 279: 33613-33622, 2004.

60. Jankun J and Skrzypczak-Jankun E: Molecular basis of specific inhibition of urokinase plasminogen activator by amiloride. Cancer Biochem Biophys 17: 109-123, 1999.

61. Jankun J and Skrzypczak-Jankun E: Binding site of amiloride to urokinase plasminogen activator depends on species. Int $\mathrm{J}$ Mol Med 8: 365-371, 2001.

62. Swiercz R, Skrzypczak-Jankun E, Merrell MM, Selman SH and Jankun J: Angiostatic activity of synthetic inhibitors of urokinase type plasminogen activator. Oncol Rep 6: 523-526, 1999.

63. Wendt MD, Rockway TW, Geyer A, McClellan W, Weitzberg M, Zhao X, Mantei R, Nienaber VL, Stewart K, Klinghofer V, et al: Identification of novel binding interactions in the development of potent, selective 2-naphthamidine inhibitors of urokinase. Synthesis, structural analysis, and SAR of N-phenyl amide 6-substitution. J Med Chem 47: 303-324, 2004.

64. Jankun J, Keck RW and Selman SH: Epigallocatechin-3-gallate prevents tumor cell implantation/growth in an experimental rat bladder tumor model. Int J Oncol 44: 147-152, 2014.

65. Jankun J, Selman SH, Swiercz R and Skrzypczak-Jankun E: Why drinking green tea could prevent cancer. Nature 387: 561, 1997.

66. Jankun J, Yang J, Zheng H, Han FQ, Al-Senaidy A and Skrzypczak-Jankun E: Remarkable extension of PAI-1 half-life surprisingly brings no changes to its structure. Int J Mol Med 29: 61-64, 2012.

67. Li X, Zheng T, Sang S and Lv L: Quercetin inhibits advanced glycation end product formation by trapping methylglyoxal and glyoxal. J Agric Food Chem 62: 12152-12158, 2014.

68. Liu P, Zou D, Yi L, Chen M, Gao Y, Zhou R, Zhang Q, Zhou Y, Zhu J, Chen K, et al: Quercetin ameliorates hypobaric hypoxiainduced memory impairment through mitochondrial and neuron function adaptation via the PGC-1 $\alpha$ pathway. Restor Neurol Neurosci 33: 143-157, 2015. 
69. Lai WW, Hsu SC, Chueh FS, Chen YY, Yang JS, Lin JP, Lien JC, Tsai $\mathrm{CH}$ and Chung JG: Quercetin inhibits migration and invasion of SAS human oral cancer cells through inhibition of NF- $\kappa \mathrm{B}$ and matrix metalloproteinase-2/-9 signaling pathways. Anticancer Res 33: 1941-1950, 2013.

70. Manolova Y, Deneva V, Antonov L, Drakalska E, Momekova D and Lambov N: The effect of the water on the curcumin tautomerism: A quantitative approach. Spectrochim Acta A Mol Biomol Spectrosc 132: 815-820, 2014.

71. Strimpakos AS and Sharma RA: Curcumin: preventive and therapeutic properties in laboratory studies and clinical trials. Antioxid Redox Signal 10: 511-545, 2008.

72. Hatcher H, Planalp R, Cho J, Torti FM and Torti SV: Curcumin: From ancient medicine to current clinical trials. Cell Mol Life Sci 65: 1631-1652, 2008.

73. Zhen L, Fan D, Yi X, Cao X, Chen D and Wang L: Curcumin inhibits oral squamous cell carcinoma proliferation and invasion via EGFR signaling pathways. Int J Clin Exp Pathol 7: 6438-6446, 2014.

74. Li MJ, Yin YC, Wang J and Jiang YF: Green tea compounds in breast cancer prevention and treatment. World J Clin Oncol 5: 520-528, 2014

75. Yang CS, Chen G and Wu Q: Recent scientific studies of a traditional chinese medicine, tea, on prevention of chronic diseases. J Tradit Complement Med 4: 17-23, 2014.

76. Yiannakopoulou EC: Green tea catechins: Proposed mechanisms of action in breast cancer focusing on the interplay between survival and apoptosis. Anticancer Agents Med Chem 14: 290-295, 2014

77. Ho YC, Yang SF, Peng CY, Chou MY and Chang YC: Epigallocatechin-3-gallate inhibits the invasion of human oral cancer cells and decreases the productions of matrix metalloproteinases and urokinase-plasminogen activator. J Oral Pathol Med 36: 588-593, 2007

78. Miocinovic R, McCabe NP, Keck RW, Jankun J, Hampton JA and Selman SH: In vivo and in vitro effect of baicalein on human prostate cancer cells. Int J Oncol 26: 241-246, 2005.

79. Yan X, Rui X and Zhang K: Baicalein inhibits the invasion of gastric cancer cells by suppressing the activity of the p38 signaling pathway. Oncol Rep 33: 737-743, 2015.

80. Zheng YH, Yin LH, Grahn TH, Ye AF, Zhao YR and Zhang QY: Anticancer effects of baicalein on hepatocellular carcinoma cells. Phytother Res 28: 1342-1348, 2014.

81. Shukla S and Gupta S: Apigenin: A promising molecule for cancer prevention. Pharm Res 27: 962-978, 2010.

82. Yang SF, Yang WE, Kuo WH, Chang HR, Chu SC and Hsieh YS Antimetastatic potentials of flavones on oral cancer cell via an inhibition of matrix-degrading proteases. Arch Oral Biol 53: 287-294, 2008

83. Brown NJ: Therapeutic potential of plasminogen activator inhibitor-1 inhibitors. Ther Adv Cardiovasc Dis 4: 315-324, 2010.

84. Rouch A, Vanucci-Bacqué C, Bedos-Belval F and Baltas M: Small molecules inhibitors of plasminogen activator inhibitor-1: an overview. Eur J Med Chem 92: 619-636, 2015.

85. Gorlatova NV, Cale JM, Elokdah H, Li D, Fan K, Warnock M Crandall DL and Lawrence DA: Mechanism of inactivation of plasminogen activator inhibitor-1 by a small molecule inhibitor. J Biol Chem 282: 9288-9296, 2007.

86. Jankun J, Al-Senaidy A and Skrzypczak-Jankun E: Can inactivators of plasminogen activator inhibitor alleviate the burden of obesity and diabetes? (Review). Int J Mol Med 29: 3-11, 2012.

87. Naessens D, Gils A, Compernolle G and Declerck PJ: Elucidation of a novel epitope of a substrate-inducing monoclonal antibody against the serpin PAI-1. J Thromb Haemost 1: 1028-1033, 2003.

88. Verhamme I, Kvassman JO, Day D, Debrock S, Vleugels N, Declerck PJ and Shore JD: Accelerated conversion of human plasminogen activator inhibitor-1 to its latent form by antibody binding. J Biol Chem 274: 17511-17517, 1999.

89. Egelund R,Einholm AP,Pedersen KE, Nielsen RW, Christensen A, Deinum J and Andreasen PA: A regulatory hydrophobic area in the flexible joint region of plasminogen activator inhibitor-1, defined with fluorescent activity-neutralizing ligands. Ligandinduced serpin polymerization. J Biol Chem 276: 13077-13086, 2001.

90. Crandall DL, Elokdah H, Di L, Hennan JK, Gorlatova NV and Lawrence DA: Characterization and comparative evaluation of a structurally unique PAI-1 inhibitor exhibiting oral in-vivo efficacy. J Thromb Haemost 2: 1422-1428, 2004.
91. Gardell SJ, Krueger JA, Antrilli TA, Elokdah H, Mayer S, Orcutt SJ, Crandall DL and Vlasuk GP: Neutralization of plasminogen activator inhibitor I (PAI-1) by the synthetic antagonist PAI-749 via a dual mechanism of action. Mol Pharmacol 72: 897-906, 2007.

92. Jankun J, Skotnicka M, Łysiak-Szydłowska W, Al-Senaidy A and Skrzypczak-Jankun E: Diverse inhibition of plasminogen activator inhibitor type 1 by theaflavins of black tea. Int J Mol Med 27: 525-529, 2011

93. Zhang YF, Xu Q, Lu J, Wang P, Zhang HW, Zhou L, Ma XQ and Zhou YH: Tea consumption and the incidence of cancer: a systematic review and meta-analysis of prospective observational studies. Eur J Cancer Prev: Nov 3, 2014 (Epub ahead of print)

94. Lee MJ, Lambert JD, Prabhu S, Meng X, Lu H, Maliakal P, Ho CT and Yang CS: Delivery of tea polyphenols to the oral cavity by green tea leaves and black tea extract. Cancer Epidemiol Biomarkers Prev 13: 132-137, 2004.

95. Yang CS, Maliakal P and Meng X: Inhibition of carcinogenesis by tea. Annu Rev Pharmacol Toxicol 42: 25-54, 2002

96. Ghosh S, Johnson JJ, Sen R, Mukhopadhyay S, Liu Y, Zhang F, Wei Y, Chapman HA and Stack MS: Functional relevance of urinary-type plasminogen activator receptor-alpha3beta1 integrin association in proteinase regulatory pathways. J Biol Chem 281: 13021-13029, 2006.

97. Lee EJ, Whang JH, Jeon NK and Kim J: The epidermal growth factor receptor tyrosine kinase inhibitor ZD1839 (Iressa) suppresses proliferation and invasion of human oral squamous carcinoma cells via p53 independent and MMP, uPAR dependent mechanism. Ann NY Acad Sci 1095: 113-128, 2007.

98. Liang X, Yang X, Tang Y, Zhou H, Liu X, Xiao L, Gao J and Mao Z: RNAi-mediated downregulation of urokinase plasminogen activator receptor inhibits proliferation, adhesion, migration and invasion in oral cancer cells. Oral Oncol 44: 1172-1180, 2008.

99. Pasini FS, Brentani MM, Kowalski LP and Federico MH: Transforming growth factor beta1, urokinase-type plasminogen activator and plasminogen activator inhibitor-1 mRNA expression in head and neck squamous carcinoma and normal adjacent mucosa. Head Neck 23: 725-732, 2001.

100. Vairaktaris E, Serefoglou Z, Avgoustidis D, Yapijakis C, Critselis E, Vylliotis A, Spyridonidou S, Derka S, Vassiliou S, Nkenke E, et al: Gene polymorphisms related to angiogenesis, inflammation and thrombosis that influence risk for oral cancer. Oral Oncol 45: 247-253, 2009.

101. Hercberg S, Kesse-Guyot E, Druesne-Pecollo N, Touvier M, Favier A, Latino-Martel P, Briançon S and Galan P: Incidence of cancers, ischemic cardiovascular diseases and mortality during 5-year follow-up after stopping antioxidant vitamins and minerals supplements: a postintervention follow-up in the SU.VI.MAX Study. Int J Cancer 127: 1875-1881, 2010.

102. Press OA, Zhang W, Gordon MA, Yang D, Lurje G, Iqbal S, El-Khoueiry A and Lenz HJ: Gender-related survival differences associated with EGFR polymorphisms in metastatic colon cancer. Cancer Res 68: 3037-3042, 2008.

103. Nainani P, Paliwal A, Nagpal N and Agrawal M: Sex hormones in gender-specific risk for head and neck cancer: A review. J Int Soc Prev Community Dent 4 (Suppl 1): S1-S4, 2014.

104. Wang YJ, Pan MH, Cheng AL, Lin LI, Ho YS, Hsieh CY and Lin JK: Stability of curcumin in buffer solutions and characterization of its degradation products. J Pharm Biomed Anal 15: 1867-1876, 1997.

105. Stout TJ, Graham H, Buckley DI and Matthews DJ: Structures of active and latent PAI-1: A possible stabilizing role for chloride ions. Biochemistry 39: 8460-8469, 2000.

106. Zeslawska E, Jacob U, Schweinitz A, Coombs G, Bode W and Madison E: Crystals of urokinase type plasminogen activator complexes reveal the binding mode of peptidomimetic inhibitors. J Mol Biol 328: 109-118, 2003.

107. Li SH, Reinke AA, Sanders KL, Emal CD, Whisstock JC, Stuckey JA and Lawrence DA: Mechanistic characterization and crystal structure of a small molecule inactivator bound to plasminogen activator inhibitor-1. Proc Natl Acad Sci USA 110: E4941-E4949, 2013

108. Shen L and Ji HF: Contribution of degradation products to the anticancer activity of curcumin. Clin Cancer Res 15: 7108; author reply 7108-7109, 2009. 